\title{
Stomach Cancer Incidence, Mortality and Survival Rate in Korean Elderly Pharmacoepidemiologic Cohort (KEPEC) in $1994 \sim 1998$
}

\author{
Nam-Kyong Choi, Kyung-Eun Youn, Dae-Seuk Heo, M.D., Ph.D. ${ }^{1}$, Seung-Mi Lee, Yooni Kim and \\ Byung-Joo Park, M.D., Ph.D. \\ Departments of Preventive Medicine and ${ }^{1}$ Internal Medicine, Seoul National University College of Medicine, Seoul, Korea
}

Purpose: This study was conducted to estimate the incidence, mortality and survival rate of stomach cancer in elderly people in Korea.

Materials and Methods: The source population was a Korean Elderly Phamacoepidemiologic Cohort (KEPEC), who were 65 years of age or older and living in Busan metropolitan city and Gyeongsangnam province, Korea. A subcohort of 38,443 persons without stomach cancer were identified before enrolling the KEPEC. The stomach cancer incidence cases were detected from three different sources, the medical claims database of the Korea Medical Insurance Corporation (KMIC), the Korea Central Cancer Registry (KCCR), and the Busan Cancer Registry (BCR). A hospital survey for abstracting the relevant information to confirm the final diagnosis of the potential cases from the medical claims database was conducted. A medical oncologist reviewed the data to confirm the final diagnoses and the date of onset. The mortality cases due to stomach cancer were detected from the mortality database at the National Statistical Office. The incidence rate, the survival rate and the mortality rate of stomach cancer and their $95 \%$ confidence intervals were estimated using SAS Windows ver. 8.1.

Results: There were 338 confirmed stomach cancer cases in the KEPEC between 1 January 1994 and 31 December 1998. The age-standardized incidence rate of

\section{서 론}

위암은 세계적으로 그 발생 빈도와 사망률이 최근 감소하

Correspondence: Byung-Joo Park, Department of Preventive Medicine, Seoul National University College of Medicine, 28, Yongon-dong, Chongno-gu, Seoul 110-799, Korea. (Tel) 82-2-740-8325, (Fax) 82-2-747-4830, (E-mail) bjpark@snu.ac.kr

Received August 13, 2003, Accepted October 1, 2003

The authors wish to acknowledge the financial support of the Korea Research Foundation made in the program year of 1998. stomach cancer in the Korean elderly population was estimated to be 351.4 per 100,000 person-years in males and 122.6 per 100,000 person-years in females. In addition, 272 stomach cancer death cases were detected in the KEPEC between 1 Jan. 1994 and 31 Dec. 1998. The age-standardized mortality rate of stomach cancer to the Korean elderly population was estimated to be 268.5 per 100,000 person-years in males and 93.7 per 100,000 person-years in females. The one-year survival rate was $62.1 \%$ in males and $63.0 \%$ in females, which was considered to be statistically similar. The three-year survival rate was $38.9 \%$ in males and $40.9 \%$ in females. The five-year survival rate was $34.8 \%$ in males and $34.7 \%$ in females.

Conclusion: The age-standardized male stomach cancer incidence rate and mortality rate to the Korean population were approximately three times higher than in female. However, there was little significant difference between males and females in terms of the overall survival rates. These results may be useful for planning a health policy for preventing and managing stomach cancer in Korea. (Cancer Research and Treatment 2003; $35: 383-390$ )

Key Words: Stomach neoplasm, Incidence, Mortality, Survival, Aged, KEPEC

고 있으나 우리나라에서는 아직 가장 흔한 암으로 중요한 사망원인 중의 하나이다(1). 한국중암암등록사업의 연례보 고서에 의하면 2001년 한 해 동안 전국에서 등록된 전체 암 발생 환자 중에서 위암으로 보고된 경우는 남자에서 $24.1 \%$ 로 가장 높았으며, 여자에서는 $15.3 \%$ 로 유방암 $(16.1 \%)$ 다음 으로 높은 비중을 차지하고 있다(2). 위암은 장년기에 주로 발견되고 있으며 특히 50세 이상 70세 미만의 연령군에서 가장 많이 발견되는 것으로 알려져 있고, 노령기의 발생률 은 평균수명의 증가와 함께 높아지는 추세에 있다 $(3,4)$. 우리나라에서는 1980년부터 중앙암등록본부(multi-hospi- 
tal central cancer registry)를 설치하여 전국의 수련병원을 대 상으로 암발생자료를 등록받기 시작하였고(5), 2002년 현재 8 개 지역암등록사업을 통하여 해당 지역주민에서의 암 발 생자료를 수집하고 있다(6). 이러한 암 등록사업의 결과 우 리나라의 암 발생에 대한 자료가 체계적으로 수집되고 있 고, 각종 암에 대한 연구가 활발히 진행되고 있으며, 2002년 에는 우리나라의 암발생통계가 국제암연구소(International Agency for Research on Cancer, IARC)의 국제공인을 받아 매 5년마다 발간하는 국제암발생통계 제8집(Cancer Incidence in Five Continents, Vol. VIII) (7)에 수록되었다.

그렇지만, 이러한 암등록사업의 결과로는 장기간의 추적 관찰을 통하여 지역사회의 구성원 개개인에 대한 정확한 인년을 산출하고, 이를 분모로 하여 평균 발생률 및 사망률 을 산출하는데 어려움이 있다. 그리고, 위암에 의한 사망수 준과 생존율에 관련된 문헌 및 통계자료의 수준은 선진국 은 물론 중국, 홍콩, 싱가포르 등과 비교하여도 열세에 놓여 있다. 병원을 기반으로 한 위암 생존율도 연구대상에 따라 상이하게 나타나고 있으며, 외국에서 연구된 결과는 인종 차이 등으로 우리나라 실정에 그대로 적용하기에는 무리가 있다(8). 그러므로, 국내 대규모 인구집단을 대상으로 한 위 암 생존율 자료가 필요하다.

국제적으로도 65 세 이상의 노인에서의 암 발생통계의 완 전성은 다른 연령층에 비하여 떨어진다(9). 이러한 시점에 서 노인인구에서의 위암 발생률, 사망률, 생존율의 추정은 위암 발생 위험요인에 관한 가설을 유도하기 위하여 반드 시 필요할 뿐만 아니라, 위암 환자의 효과적인 관리를 위한 사회경제적 측면의 대책마련에도 필수적이다. 이에 본 연 구는 우리나라에서 대표성을 가진 지역사회의 노인인구를 대상으로 가능한 모든 자료원을 이용하여 위암의 발생률, 사망률, 그리고 생존율을 추정하고자 수행되었다.

\section{대상 및 방법}

\section{1) 연구대상}

본 연구의 대상자는 부산광역시의 공무원 및 사립학교 교직원을 대상으로 1993년 1월 1일부터 1998년 12월 31일 사이에 의료보험관리공단의 피보험자 및 피부양자 자격을 가진 65세 이상의 노년층을 대상으로 구축된 한국노인약물 역학코호트(Korean Elderly Pharmacoepidemiologic Cohort, $\mathrm{KEPEC}$ ) (10)로부터 선정되었다. 코호트를 구축하여 대상자 의 자료가 안정적으로 수집되었던 1994년부터 추적관찰을 시작하였으므로, 연구대상은 1994년 1월 1일부터 1998년 12월 31일 사이에 코호트 구성원 자격이 있는 대상자 중에 서 1994년 이전에 위암을 포함한 각종 암이 발생하였던 자
Table 1. The sex and age distribution of Korean Elderly Pharmacoepidemiologic Cohort (KEPEC), and Korea, $1994 \sim 1998$

\begin{tabular}{|c|c|c|c|c|}
\hline \multirow{2}{*}{ Age } & \multicolumn{2}{|c|}{ KEPEC } & \multicolumn{2}{|c|}{ Korea } \\
\hline & $\begin{array}{c}\text { Male } \\
\text { No. }(\%)\end{array}$ & $\begin{array}{l}\text { Female } \\
\text { No. }(\%)\end{array}$ & $\begin{array}{c}\text { Male } \\
\text { No. }(\%)\end{array}$ & $\begin{array}{c}\text { Female } \\
\text { No. }(\%)\end{array}$ \\
\hline $65 \sim 69$ & $\begin{array}{l}7,145 \\
(50.1)\end{array}$ & $\begin{array}{r}10,563 \\
(43.7)\end{array}$ & $\begin{array}{r}420,873 \\
(43.2)\end{array}$ & $\begin{array}{r}623,106 \\
(37.4)\end{array}$ \\
\hline $70 \sim 74$ & $\begin{array}{l}3,852 \\
(27.0)\end{array}$ & $\begin{array}{l}6,089 \\
(25.2)\end{array}$ & $\begin{array}{r}293,696 \\
(30.1)\end{array}$ & $\begin{array}{r}468,848 \\
(28.2)\end{array}$ \\
\hline $75 \sim 79$ & $\begin{array}{l}2,059 \\
(14.5)\end{array}$ & $\begin{array}{l}3,857 \\
(15.9)\end{array}$ & $\begin{array}{r}160,498 \\
(16.5)\end{array}$ & $\begin{array}{r}295,175 \\
(17.7)\end{array}$ \\
\hline $80 \sim 84$ & $\begin{array}{r}865 \\
(6.1)\end{array}$ & $\begin{array}{r}2,390 \\
(9.9)\end{array}$ & $\begin{array}{r}71,267 \\
(7.3)\end{array}$ & $\begin{array}{r}174,924 \\
(10.5)\end{array}$ \\
\hline $85+$ & $\begin{array}{r}330 \\
(2.3)\end{array}$ & $\begin{array}{r}1,293 \\
(5.3)\end{array}$ & $\begin{array}{r}28,370 \\
(2.9)\end{array}$ & $\begin{array}{r}103,448 \\
(6.2)\end{array}$ \\
\hline Total & $\begin{array}{l}14,251 \\
(100.0)\end{array}$ & $\begin{array}{l}24,192 \\
(100.0)\end{array}$ & $\begin{array}{r}974,704 \\
(100.0)\end{array}$ & $\begin{array}{r}1,665,501 \\
(100.0)\end{array}$ \\
\hline
\end{tabular}

를 제외한 총 38,443 명으로 남자 14,251 명(37.1\%), 여자 24,192명(62.9\%)이었다. 제외 대상은 코호트 구성원 중에서 1993년에서 1998년 사이에 중앙암등록자료에 등록된 사람 중에서 1994년 이전에 각종 암이 발생하였거나, 잠재적인 위암환자를 대상으로 한 부산지역 병원방문조사결과 1994 년 이전에 위암 발생이 확인된 126 명이었다. 특히, 제외 대 상자 중 위암으로 제외된 경우는 44명이었다. 연구대상은 1995년 기준 우리나라 전체 노인 인구의 성비와 매우 유사 하였으며, 여자가 남자보다 1.7 배 더 많은 전형적인 노인인 구집단의 특성을 보였다(Table 1).

\section{2) 위암 발생 및 사망 확인}

위암 환자의 발생은 다음의 세 가지 자료원을 토대로 확 인하였다. 위암 발생일은 IARC의 규칙에 따라 위암 환자가 의료기관과 처음으로 접촉한 일자로 정의하였다(12,23).

한국노인약물역학코호트 구성원을 대상으로 1994년 1월 1일부터 1998년 12월 31일까지 의료보험관리공단에 청구된 진단명을 검색하여 위암 환자일 가능성이 있는 증례들을 일차 선별하였다. 즉, 표준질병분류가 ICD-9 151 (malignant neoplasm of stomach), ICD-10 C16 (malignant neoplasm of stomach), ICD-10 D00.2 (in situ neoplasm of stomach), ICD-10 D37.1 (neoplasm of uncertain or unknown behavior of stomach)인 경우를 잠재적인 위암 발생자로 정의하고 이들 에서 실제로 위암이 발생하였는지를 부산지역의 병원방문 
조사를 통하여 확인하였다. 1994년 1월부터 1996년 6월까 지 확인된 잠재적인 위암 환자 115명에 대하여 1996년 7월 에 24개 병원을 대상으로 1차 병원방문조사를 실시하였으 며, 1996년 7월부터 1998년 12월 사이에 확인된 잠재적 위 암 환자 140 명을 대상으로 35 개 병원을 대상으로 2차 병원 방문조사를 2000년 7월에 실시하였다. 2차 병원방문조사 대상자 140 명 중 19 명은 1 차 대상자와 동일하였다. 위암에 대한 병록과 검사결과를 요약할 수 있는 표준병록요약지를 개발하였고, 의과대학 본과 2,3 학년 학생들을 병원방문조 사원으로 선발하여 교육하였다. 예비조사를 통하여 조사원 들 간에 의무기록과 검사결과를 요약하는 과정 및 방법을 표준화하였고, 이들 조사원들로 하여금 방문조사 대상 병 원을 방문하여 환자들의 의무기록과 조직생검을 포함한 검 사결과를 요약하도록 하였다. 잠재적인 위암환자군에 대하 여 요약된 표준병록요약지를 종양학 전문의가 검토하여 환 자를 다섯 군(Definite, Probable, Possible, Unlike, Unknown) 으로 분류하였으며, 최초 발생일을 결정하였다. 최종 진단 에서 'Definite'는 병리학적으로 확진된 환자군으로 조직생 검 결과 위암 양성으로 판정된 경우이었고, 'Probable'은 조 직생검 이외의 방법인 상부 위내시경검사, 위장관검사, 복 부 초음파촬영 등에 의하여 위암 양성으로 판정된 경우이 었다. 'Possible'은 방문조사대상병원 이외의 병원에서 이미 위암으로 진단받은 환자가 방문조사대상병원으로 이송된 경우나 방문조사대상병원에서 검사결과가 첨부되어 있지 않으나 검사를 실시하였다는 기록이 있으며 결과를 주치의 가 확인하여 위암 양성을 의무기록상에 기재한 경우이었 다. 'Unlike'는 의무기록상 명백히 다른 질병인 경우이었으 며, 'Unknown'은 정보가 불충분하여 위암 발생 여부에 대한 판정이 불가능한 경우이었다. 본 연구에서는 종양학 전문 의에 의해서 판단된 진단기준 중에서 'Definite', 'Probable', 'Possible'을 최종 확진된 위암 발생환자로 정의하였다.

코호트 구성원 중에서 1994년부터 1998년까지 중앙암등 록자료에 위암으로 등록된 경우와, 부산지역암등록자료에 서 1995년부터 1997년까지 위암으로 등록된 환자를 주민등 록번호를 이용하여 확인하였다. 동일한 환자가 여러 자료 원에서 확인된 경우에는 각 자료원에 의하여 조사된 위암 발생일 중 가장 빠른 시점을 위암 발생일로 정의하였다.

또한, 한 명의 대상자가 두 가지 이상의 암으로 진단된 경우 종양학 전문의에 의하여 전이암과 다중원발암으로 구 분하였다. 다중원발암 중 하나로 위암이 발생한 경우에는 위암 발생자로 간주하며, 위암이 발생한 날짜를 위암 발생 일로 정의하였으며, 전이암인 경우에는 발생된 암 중 위암 이 최초로 발생한 경우에만 위암 발생자로 인정하였다.

위암 환자의 사망은 1994년부터 1998년까지의 통계청 사
망자료에서 사망원인 진단명을 검색하여 ICD-9 151, ICD-10 C16, D00.2, D37.1인 경우를 위암 사망자로 정의하 였다. 사망자료의 특성상 주민등록번호 13자리의 뒷 7자리 중 한 자리 숫자가 무작위로 삭제되어 12자리만 확인 가능 하므로 인적사항인 이름, 나이, 거주지 등을 이용하여 한국 노인약물역학코호트 구성원과 동일인 여부를 확인하였다.

생존율을 산출하기 위하여 병원방문조사와 중앙암등록 자료, 부산지역암등록자료에 의해 위암 발생자로 정의된 대상자에 대한 사망일을 1994년부터 2001년까지의 통계청 사망자료를 이용하여 추적하였다.

\section{3) 발생률, 사망률, 생존율 산출 방법}

성별, 연령별(5세 간격) 위암 발생률과 위암 사망률을 산 출하기 위하여 관찰대상자 개인에 대한 추적조사 개시일과 추적조사 종료일을 다음과 같이 정의하였다. 1994년 이전 에 코호트 구성원 자격을 취득한 경우에 추적조사 개시일 은 1994년 1월 1일로 하였으며, 1994년 1월 1일 이후에 코호 트 구성원이 된 경우는 코호트 구성원 자격을 취득한 날을 추적조사 개시일로 정의하였다. 추적조사 종료일은 위암이 발생하지 않은 대상자 중에서 1998년 12월 31일 이전에 코 호트구성원 자격을 상실한 경우 자격상실일을 추적조사종 료일로 정의하였고, 1998년 12월 31일 이후에 코호트구성 원 자격을 상실한 경우는 1998년 12월 31일을 추적조사종 료일로 하였으며, 만약 자격상실일보다 사망일이 빠른 경 우에는 사망일을 추적조사종료일로 하였다. 위암이 발생한 대상자는 위암 발생일을 추적조사 종료일로 정의하였다. 위암 발생률의 분모로 추적조사종료일과 추적조사개시일 의 차이를 각 개인별로 관찰된 인-년(person-years)으로 정의 하였다. 위암 사망률의 경우 분모인 인-년은 발생률의 분모 와 동일한 방법으로 계산하되, 위암 발생자의 추적조사종 료일은 사망일, 코호트 구성원 자격 상실일, 1998년 12월 31 일 중 가장 빠른 날로 정의하였다.

위암 발생률은 한국노인약물역학코호트 구성원 중 1994 년부터 1998년까지 새로 위암이 발생한 사람 수를 한국노 인약물역학코호트 구성원들을 대상으로 추적 관찰한 인-년 의 합으로 나누어서 성별, 연령별 10 만인-년당 연간 위암 발생률(11)을 구하였으며, 각 위암 발생률에 대한 $95 \%$ 신뢰 구간(12)을 추정하였다. 한국노인약물역학코호트에서 구한 위암 발생률을 근거로 1995년 대한민국 인구와 세계인구를 표준인구로 하여 직접표준화방법을 적용하여 위암에 대한 연령보정 연 평균발생률을 산출하였다.

위암 사망률은 한국노인약물역학코호트 구성원 중 1994 년부터 1998년까지 위암으로 사망한 사람 수를 성별 연령 별 평균 인구의 관찰기간 합으로 나누어 성별, 연령별 사망 


\section{Cancer Research and Treatment 2003;35(5)}

률(11)을 구하고, 각 사망률에 대한 $95 \%$ 신뢰구간(12)을 추 정하였다. 1995년 대한민국 인구와 세계인구를 표준인구로 하여 직접표준화방법을 적용하여 위암에 대한 연령보정 연 평균 사망률을 산출하였다.

한국노인약물역학코호트 구성원 중 1994년 이후 새로이 위암이 발생한 자를 대상으로 성별로 1 년에서 5 년 위암생 존율을 산출하였다. 본 연구에서는 각 환자의 생존시간이 나 중도절단된 시간을 관측할 수 있을 때 쓰이는 카플란-마 이어 방법(Kaplan-Meier method)을 이용하여 생존율을 추정 하였고, 시간 $t$ 에서 생존율 $\mathrm{S}(\mathrm{t})$ 의 추정치는

$$
\widehat{S}(t)=\prod_{X_{(i)} \leq t}\left(\frac{n_{i}-d_{i}}{n_{i}}\right)^{\delta(i)}
$$

로 산출하였다. 여기서 시간 $t$ 가 1 년, 3 년, 및 5 년인 경우, $\hat{\mathrm{S}}(\mathrm{t})$ 는 각각 1 년, 3 년, 및 5년 생존율이 된다. 성별 생존율의 차이를 분석하기 위하여 로그순위검정법(Log-rank test)을 시행하였다. 모든 통계분석은 Windows SAS ver 8.1을 이용 하였다.

\section{결 과}

\section{1) 위암 발생 환자와 사망 환자의 확인 결과}

한국노인약물역학코호트 구성원 중 1994년부터 1998년 까지 의료보험관리공단에 진단명이 위암으로 청구된 코호 트구성원을 대상으로 병원방문조사를 실시한 결과 병원방 문조사 대상 236명 중에서 위암이 발생한 대상자는 187명 이었고, 그 중 36 명은 1994년 이전에 위암이 발생한 경우로 연구대상에서 제외되었으며, 151명은 1994년 이후 새로이 위암이 발생한 것으로 확인되었다. 한국노인약물역학코호 트 구성원 중에서 1994년에서 1998년의 중암암등록자료에 위암으로 등록된 사람은 245명으로 집계되었으며, 1995년 부터 1997년의 부산지역암등록자료에는 159 명이 위암으로 등록되었다. 위의 세 자료원 모두에서 동시에 관찰된 대상 자는 50명이었고, 한국노인약물역학 코호트 구성원 중에서 세 자료원 중 하나 이상의 자료원으로부터 위암 발생자로 확인된 사람은 모두 338 명으로 남자 211명, 여자 127 명이었 다. 통계청 사망자료에서 사망원인이 위암으로 보고된 대 상자는 모두 272 명이었으며 남자는 170 명, 여자는 162 명이 었다.

중앙암등록자료, 부산지역암등록자료, 사망자료에서 위 암 발생 또는 사망자를 확인하기 위한 진단명으로 ICD-10 D00.2, D37.1을 포함하였으나, 실제 데이터에서 위 진단명 을 가진 대상자가 없었으므로 결과적으로 위암 발생자 또 는 사망자에 ICD-10 D00.2, D37.1의 진단명인 대상자가 포 함되지 않았다.

\section{2) 위암 발생률}

남자에서 위암 조발생률은 10 만인-년당 375.2 명 $(95 \%$ 신 뢰구간: 324.6 416.0)으로 여자에서의 조발생률보다 약 3 배 높은 것으로 추정되었다. 남자의 연령별 발생률은 10 만 인-년당 65 69세 247.6명, 70 74세 397.2명, 75 79세 526.2명, 80 84세 418.5명, 85세 이상에서 260.9명으로, 79 세까지는 급격히 증가하다가 80 세 이후에는 발생률이 감소 하는 것으로 나타났다. 성별, 연령별 위암 발생률을 1995년 우리나라 전체 인구에 보정하여 산출한 발생률은 남자 10 만인-년당 351.4명(95\% 신뢰구간: 304.0 390.9)이었으며, 세계표준인구에 보정한 표준화 위암 발생률은 남자에서 10 만인-년당 343.3명(95\% 신뢰구간: 297.0 382.3)으로 추정 되었다(Table 2).

여자에서의 위암 조발생률은 10 만인-년당 124.5 명(95\% 신뢰구간: 102.9 148.6)으로 추정되었다. 연령별로는 10 만 인-년당 65 69세 107.0명, 70 74세 134.6명, 75 79세 152.9명, 80 84세 117.0명, 85세 이상에서 85.2명으로 75 79세군에서 가장 높은 발생률을 보였으며, 남자와 동일하 게 80 세 이후 군에서는 발생률이 떨어지는 것으로 나타났 다. 1995년 우리나라 전체 인구에 보정하여 산출한 발생률 은 여자 10만인-년당 122.6 명 (95\% 신뢰구간: 101.3 146.5) 으로 나타났으며, 세계표준인구에 보정한 표준화 위암 발 생률은 10만인-년당 120.6명(95\% 신뢰구간: 99.6 144.3)으 로 추정되었다(Table 3).

\section{3) 위암 사망률}

남자에서 위암 조사망률은 10만인-년당 302.3명(95\% 신

Table 2. Age-specific incidence rates of stomach cancer per 100,000 person-years in male in Korean Elderly Pharmacoepidemiologic Cohort (KEPEC), 1994 1998

\begin{tabular}{lccc} 
Age & $\begin{array}{c}\text { Observed } \\
\text { period } \\
\text { (person-years) }\end{array}$ & $\begin{array}{c}\text { No. of } \\
\text { incident } \\
\text { cases }\end{array}$ & $\begin{array}{c}\text { Incidence rate per } \\
100,000 \text { Person-years } \\
(95 \% \text { CI })\end{array}$ \\
\hline $65 \sim 69$ & 16,963 & 42 & $247.6(172.7 \sim 284.5)$ \\
$70 \sim 74$ & 19,887 & 79 & $397.2(309.6 \sim 441.5)$ \\
$75 \sim 79$ & 11,592 & 61 & $526.2(394.2 \sim 578.2)$ \\
$80 \sim 84$ & 5,496 & 23 & $418.5(247.5 \sim 470.6)$ \\
$85+$ & 2,300 & 6 & $260.9(52.1 \sim 331.7)$ \\
\hline Total & 56,238 & 211 & $375.2(324.6 \sim 416.0)$
\end{tabular}

Age adjusted rate for the Korean population as of 1995 (95\% CI) $=351.4(304.0 \sim 390.9)$, Age adjusted rate for the world population $(95 \%$ CI $)=343.3(297.0 \sim 382.3)$ 
Table 3. Age-specific incidence rates of stomach cancer per 100,000 person-years in female in Korean Elderly Pharmacoepidemiologic Cohort (KEPEC), 1994 1998

\begin{tabular}{lccc}
\hline Age & $\begin{array}{c}\text { Observed } \\
\text { period } \\
\text { (person-years) }\end{array}$ & $\begin{array}{c}\text { No. of } \\
\text { incident } \\
\text { cases }\end{array}$ & $\begin{array}{c}\text { Incidence rate per } \\
100,000 \text { Person-years } \\
(95 \% \text { CI })\end{array}$ \\
\hline $65 \sim 69$ & 26,161 & 28 & $107.0(67.4 \sim 132.6)$ \\
$70 \sim 74$ & 32,686 & 44 & $134.6(94.8 \sim 161.7)$ \\
$75 \sim 79$ & 20,924 & 32 & $152.9(99.9 \sim 182.9)$ \\
$80 \sim 84$ & 12,825 & 15 & $117.0(57.8 \sim 147.1)$ \\
$85+$ & 9,390 & 8 & $85.2(26.2 \sim 117.8)$ \\
\hline Total & 101,986 & 127 & $124.5(102.9 \sim 148.6)$
\end{tabular}

Age adjusted rate for the Korean population as of 1995 (95\% CI) $=122.6(101.3 \sim 146.5)$, Age adjusted rate for the world population $(95 \% \mathrm{CI})=120.6(99.6 \sim 144.3)$

Table 4. Age-specific mortality rates of stomach cancer by sex per 100,000 person-years in Korean Elderly Pharmacoepidemiologic Cohort (KEPEC), 1994 1998

\begin{tabular}{lcc}
\hline \multicolumn{1}{c}{ Age } & $\begin{array}{c}\text { Male } \\
\text { Mortality rate per } \\
100,000 \text { pys }(95 \% \mathrm{CI})\end{array}$ & $\begin{array}{c}\text { Female } \\
\text { Mortality rate per } \\
100,000 \text { pys }(95 \% \mathrm{CI})\end{array}$ \\
\hline $65 \sim 69$ & $129.7(75.5 \sim 158.9)$ & $65.0(34.1 \sim 86.8)$ \\
$70 \sim 74$ & $286.6(212.2 \sim 325.2)$ & $76.5(46.5 \sim 98.5)$ \\
$75 \sim 79$ & $534.9(401.7 \sim 587.2)$ & $157.7(103.9 \sim 188.0)$ \\
$80 \sim 84$ & $382.1(218.7 \sim 432.7)$ & $101.4(46.3 \sim 130.6)$ \\
$85+$ & $347.8(106.8 \sim 413.8)$ & $149.1(71.0 \sim 183.8)$ \\
\hline Crude rate & $302.3(256.8 \sim 339.3)$ & $100.0(80.6 \sim 121.8)$ \\
\hline
\end{tabular}

Age adjusted rate for the Korean population as of 1995 in male $(95 \% \mathrm{CI})=268.5(228.1 \sim 303.3)$, Age adjusted rate for the world population in male $(95 \% \mathrm{CI})=266.0 \quad(226.0 \sim 300.7)$, Age adjusted rate for the Korean population as of 1995 in female $(95 \%$ CI $)=93.7(75.5 \sim 114.8)$, Age adjusted rate for the world population in female $(95 \% \mathrm{CI})=90.1 \quad(72.6 \sim 110.8)$

뢰구간: 256.8 339.3)이었고, 여자에서는 100.0 명(95\% 신뢰 구간: 80.6 121.8)으로 산출되었다. 남자에서 위암 사망률 이 여자에서의 위암 사망률보다 약 3 배 높은 것으로 관찰되 었으며, 남자와 여자 모두 75세 이상 79세 이하 연령군에서 사망률이 가장 높게 나타났다. 성별, 연령별 위암 사망률을 1995년 우리나라 전체 인구에 적용하여 산출한 표준화 위암 사망률은 남자 10만인-년당 268.5명(95\% 신뢰구간: 228.1 303.3), 여자 10만인-년당 93.7명(95\% 신뢰구간: $75.5 \sim 114.8)$ 으로 추정되었으며, 세계표준인구에 성별, 연령별 위암 사

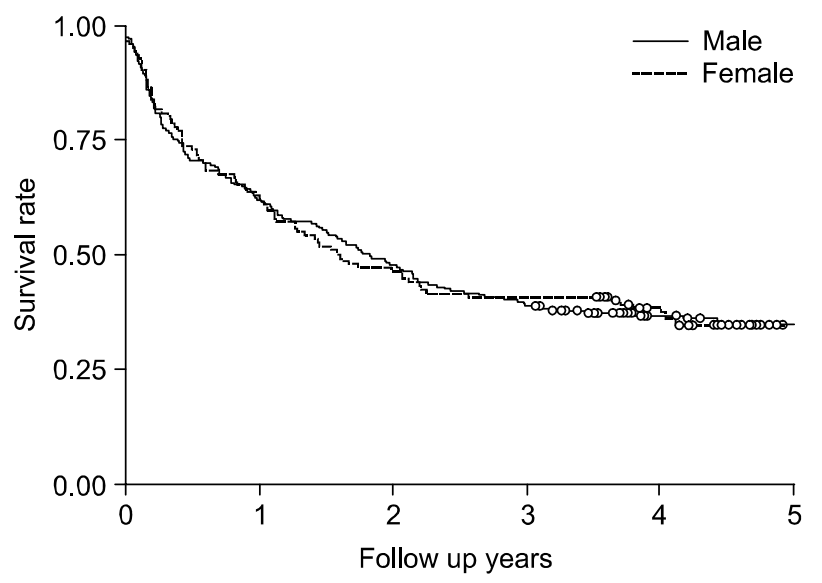

Fig. 1. Survival curve of stomach cancer produced by the Kaplan-Meier method in the Korean Elderly Pharmacoepidemiologic Cohort (KEPEC), 1994 2001.

망률을 적용하여 산출한 표준화 위암 사망률은 남자에서 10 만인-년당 266.0명(95\% 신뢰구간: 226.0 300.7), 여자에 서 10만인-년당 90.1명(95\% 신뢰구간: 72.6 110.8)으로 추 정되었다(Table 4).

\section{4) 위암 생존양상}

65 세 이상 노인 위암 발생자 중 남자의 1 년 생존율은 $62.1 \%$ (95\% 신뢰구간: 55.5 68.6), 2년 생존율은 $47.9 \%$ (95\% 신뢰구간: 41.1 54.6)이었으며, 3년 생존율은 $38.9 \%$ (95\% 신뢰구간: 32.3 43.3)이었다. 4년 생존율은 $36.8 \%$ (95\% 신뢰구간: $30.3 \sim 43.3$ )이고, 5년 생존율은 $34.8 \%$ (95\% 신뢰구간: $28.2 \sim 41.3$ )이었다. 생존시간의 중앙값(median survival time)은 $3.04 \pm 0.19$ 년이었다. 여자 노인의 1 년 생존 율은 63.0\% (95\% 신뢰구간: 54.6 71.4)이었고, 2년 생존율 은 $46.5 \%$ (95\% 신뢰구간: $37.8 \sim 55.1$ ), 3년 생존율은 $40.9 \%$ (95\% 신뢰구간: $32.4 \sim 49.5$ )이었다. 4년 생존율은 $38.4 \%$ (95\% 신뢰구간: 29.9 46.9)이고, 5년 생존율은 34.7\% (95\% 신뢰구간: $26.3 \sim 43.1$ 이었다. 생존시간의 중앙값은 $2.16 \pm$ 0.15년이었고, 남자와 여자간의 위암생존율에 통계적으로 유의한 차이는 없었다( $\mathrm{p}=0.92)$ (Fig. 1).

\section{고 찰}

본 연구대상인 한국노인약물역학코호트의 모집단은 의 료보험관리공단의 피보험자 및 피부양자로 성별, 연령별 인구구성이 우리나라 전체 인구구조와 유사하였다. 의료보 험관리공단의 피보험자는 공무원과 사립학교 교직원으로 구성되는데, 이들의 사회경제적 수준의 분포는 비교적 고 
른 것으로 알려져 있으므로(13), 피부양자까지 감안한다면 인구구성에 있어 이들을 통해 우리나라 암 발생수준을 추 정하는 데 큰 무리가 없을 것으로 판단된다. 대도시를 중심 으로 한 자료를 사용하여 전국의 암 발생률을 추계하려면 지역적인 차이(도시, 농촌), 사회경제적인 수준 차이 등을 고려하여야 하는데(14) 우리나라에서는 발생률 산출과정에 서 도농 간의 차이가 큰 장애가 되지않는 것으로 알려져 있다(15).

본 연구에서는 가능한 여러 자료원을 통합하여 발생률을 추정하므로써 암 발생자 파악시 발생하기 쉬운 위음성률을 줄이고, 단일 자료원의 불완전성으로 인한 과소평가(16)를 최소화하려고 노력하였다. 자발적으로 참여하는 대형 의료 기관들만을 대상으로 한 암등록사업에서는 노년층 암환자 자료의 누락이 상당 부분 발생하므로(17), 사망자료에서만 암환자로 확인된 암등록자(DCO, Death Certification Only)의 분율을 줄이기 위하여 병원방문조사를 통한 의무기록지의 확인으로 중소병원에서 진단받은 암환자들까지 포함시켜 노인인구에서의 암 발생 확인의 충실도를 증대시켰다. 또 한, 지방의 경우 서울과 달리 타 지역으로 가서 진단과 치료 를 받을 가능성을 반드시 고려해야하므로 부산지역암등록 자료 뿐만 아니라 중앙암등록자료에 등록된 코호트구성원 을 확인하는 과정을 거쳤다(18).

세계적으로 지난 수십 년 동안 위암의 발생률은 급격히 감소하고 있고 우리나라도 예외는 아니다. 그러나, 위암은 암으로 인한 사망원인 가운데 2 위를 차지하고 있으며 연간 100 만여 명이 사망할 정도로 여전히 치명적인 질환이다(19 21). 본 연구의 결과 연령이 증가함에 따라 남, 녀 모두 위암 의 발생률이 증가하였으나, 80세 이후에 감소추세를 보이 면서 85세 이상 연령군에서는 발생률이 크게 감소하였다. 이는 선진국의 신뢰성있는 암 발생률자료에서 유방암이나 자궁암 등의 일부 암을 제외하고는 연령에 따라서 그 발생 률이 지수적으로 증가하는 것과는 대조적이다. 본 연구에 서 위암 발생은 의료보험관리공단에 청구된 진단명을 검색 하여 위암으로 의심되는 증례를 일차 선발하여 병원방문조 사를 통하여 의무기록을 확인한 후, 종양학 전문의에 의해 확인하는 방법과, 중앙암등록자료와 부산지역암등록자료 를 이용하여 엄격한 기준에 의하여 위암 발생자를 정의하 였다. 그러나, 본 연구 대상이 65세 이상의 노인이었으므로 노인인구집단의 특성상 의료이용도가 낮아(17) 위암이 발 생하였으나 병원에서 진단되지 않아 확인이 불가능하여 발 생률이 과소 추정되었을 가능성을 배제할 수는 없다. 그리 고, 이러한 경우에 사망 시에만 관찰되어 전 연령을 대상으 로 하는 암등록자료의 사망자료에서만 암 환자로 확인된 암등록자(DCO)보다 높게 나타난 원인으로 추정된다.
국제암발생통계 제8집(7)에 수록된 부산광역시의 65 세 이상 노인의 위암 발생률을 세계표준인구에 연령보정하여 연령보정 위암 발생률(age-adjusted rate, ASR)을 산출하여 비교하였다. 부산광역시 남자 노인의 연령 보정한 위암 발 생률은 10 만명당 538.8 명이고, 여자는 10 만명당 201.9 명으 로 한국노인약물역학코호트 구성원의 연령보정 발생률에 비하여 높게 나타났다. 그리고, 세계표준인구에 연령을 보 정한 연령보정 위암 발생률을 산출하여 연령별 위암 발생 수준을 세계 여러 나라의 민족과 지역을 대상으로 비교였 을 때, 동양권에서는 본토에 거주하는 한국인(KEPEC), 일 본인(오사카), 중국인(상하이)과 미국 LA에 거주하는 한국 인, 일본인, 중국인을 비교하고, 다른 인종으로 미국에 거주 하는 백인과 흑인(7)을 비교 대상으로 삼았다. 한국노인약 물역학코호트 남자 구성원의 연령별 위암 발생률은 오사카 에 거주하는 일본인 남자(447.9명/10만명)보다 낮고, 상하이 에 거주하는 중국인 남자(251.9명/10만명)보다 높은 것으로 나타났다. 그리고, 미국에 거주하는 백인(54.7명/10만명) 또 는 흑인 남자(105.3명/10만명)에 비하여 높은 발생률을 보였 다. 한국노인약물역학코호트의 여자 위암 발생률은 본토에 사는 일본인(167.3명/10만명), 중국인 여자(126.6명/10만명) 보다 낮은 발생률을 보였으나, 미국에 거주하는 백인(21.9 명/10만명) 또는 흑인 여자(41.4명/10만명)에 비하여 높은 발생률을 보였다. 위암 발생률은 황인, 흑인, 백인 순으로 높아 인종간의 발생률 차이를 뚜렷하게 보였다. 또한, 인종 간 차이 뿐 아니라 동일 인종의 지역간 차이를 보였는데, 본토에 거주하는 한국인, 일본인, 중국인은 미국에 거주하 는 백인 또는 흑인에 비하여 높은 위암 발생률을 보였으며, 흑인이 백인보다 위암 발생률이 높았다. 그러므로, 유전적 인 인자가 위암 발생에 관여함을 추정할 수 있었다. 그리고 일본인과 중국인의 경우 남, 녀 모두에서 미국으로 이주한 경우에 위암 발생률이 현저하게 낮아졌으므로 위암 발생의 위험요인으로 유전적 인자 뿐 아니라 환경적 인자도 큰 영 향을 미칠 수 있다는 결론을 내릴 수 있다.

위암 발생의 주된 위험요인 중의 하나로 훈제식품이나 건조식품, 염장식품 등이 있는데 이들 식품에 많이 포함되 어 있는 질산염(nitrate)이 세균에 의해 발암물질인 아질산 염(nitrite)으로 전환되어 위암 발생을 유발시킨다는 연구결 과가 보고된 바 있으며, 이러한 세균은 적절히 보관되지 못 해 부분적으로 썩거나 상한 음식을 먹어 유입되는 것으로 추정되었다. 위암의 발생 빈도가 사회경제적으로 낮은 계 층과 후진국에서 상대적으로 높다는 사실과 냉장고의 보급 이 보편화되고 식생활이 개선되어 신선한 음식을 상대적으 로 많이 섭취하게 되면서 선진국에서 위암의 발생률이 크 게 감소한 사실이 이러한 가설을 뒷받침한다(22). 그러므로, 
이민 후 식생활의 변화, 생활환경의 변화 등이 위암 발생의 감소에 영향을 미친 것으로 유추할 수 있다. 그러나, 한국인 이주민에서는 일본인 이주민 또는 중국인 이주민과 같은 현저한 감소추세는 보이지 않았는데, 이는 한국 이주민의 역사가 비교적 짧아 대상이 충분하지 않고, 본 연구에서의 발생률 추정방법과 LA에 거주하는 한국인의 위암 발생률 의 추정 방법의 차이로 인한 것으로 추정된다. 그러므로, 환 경인자가 위암 발생에 미치는 영향에 대한 가설을 확인하 고 정확한 위험요인을 구명하기 위하여 추후 잘 계획된 이 민연구를 수행할 필요가 있다.

그렇지만, 한국노인약물역학코호트 구성원의 위암 발생 률은 관찰기간이 코호트 구성원 개개인에 따라 동일하지 않기 때문에 한 집단에서 질병발생수를 그 집단내의 모든 개인에 대한 관찰기간의 합으로 나누어 평균발생률 (incidence density)을 산출하였으나, 세계 여러 나라의 민족 과 지역을 대상으로 한 국외의 자료(7)는 고정된 인구집단 에서 일정 기간 동안에 질병을 얻게 되는 사람의 분율인 누적발생률(cumulative incidence)을 산출하였으며, 사망자 료에서만 암환자로 확인된 암등록자(DCO)를 발생률의 분 자에 포함시켰기 때문에 발생률의 정의에 차이가 있었다. 이는 장기간의 암의 발생, 사망을 관찰하는 암등록의 경우 에는 매년 일정한 분율의 암 환자가 사망자료에서 확인가 능하다는 가정하에 정상적인 방법으로 등록되지 않고 사망 자료에서만 암환자로 확인된 암등록자(DCO)를 발생률 산 출의 분자로 포함하므로(23), 누적발생률의 분모는 추적기 간의 평균 주민등록인구이므로 본 연구의 발생률의 정의와 차이가 있어 직접적인 비교는 어려웠다. 그러나 직접적으 로 비교 가능한 적절한 자료를 확보하지 못하여 부득이 두 자료를 비교 분석하였다.

사망률은 남, 여 모두에서 75세에서 79세 사이에 가장 높 았다. 본 연구에서는 통계청의 사망자료에 사인이 위암인 대상자를 위암 사망자로 정의하였다. 그러나, 1994년 사망 원인통계연보에 의하면 사망신고 시 의사의 진단서 첨부율 은 65 세에서 69 세 사이가 $46.3 \%, 70$ 세에서 74 세에 $41.0 \%$, 75세에서 79 세가 $35.8 \%, 80$ 세에서 84 세가 $29.8 \%$ (24)로서 연 령이 증가함에 따라 의사의 사망진단서 첨부율이 급격히 낮아지므로 사망자료의 타당성 문제는 노인인구에서 더욱 심각할 것으로 보인다. 그러므로 실제 위암이 아닌 경우에 도 위암으로 인한 사망으로 확인된 경우가 있어 사망률이 과대 추정되었을 가능성이 있다. 그렇지만, 부산광역시는 사망자의 사인분류가능 건수가 $96 \%$, 의사 진단 건수가 $86.6 \%(24)$ 로 전국에서 가장 높으므로 다른 지역에 비하여 비교적 타당성이 높다고 할 수 있다. 앞으로 사망신고 시 의사의 사망진단서를 반드시 첨부하도록 법으로 규정하여
의사진단서 첨부율을 높이는 것과 지역사회를 대상으로 하 여 사망원인의 타당성을 보장할 수 있는 사망률 추정연구 를 수행하는 것이 요구된다.

본 연구에서 위암으로 확인된 대상자 중 남자의 5년 생존 율은 $34.8 \%$ 로 우리나라 전 연령 남자의 5년 위암 생존율인 $39.3 \%(25)$ 에 비하여 낮았으며, 노인 여자에서도 5년 생존율 은 $34.7 \%$ 전 연령 여자의 5년 위암 생존율인 $41.2 \%(25)$ 에 비하여 낮은 것으로 나타났다. 본 연구에서는 연구 대상이 65세 이상의 노인이므로 전체 인구에 비하여 질병의 예후 가 좋지 않아 우리나라 전체 인구의 위암 생존율보다 낮게 나타난 것으로 판단된다. 그러나, 본 연구에서는 2002년 1 월 1 일 이후 사망한 대상자에 대한 사망일을 추적하지 못하 여 중앙값이 다소 낮게 추정되었을 우려가 있다. 생존율에 대한 대규모 인구집단에서의 통계량은 예후 및 치료효과의 판정에 필수불가결한 기초자료로써, 위암으로 진단받은 환 자에 대한 상담자료로 중요한 역할을 하며, 집단검진의 효 과 및 효율의 판정, 공중보건학적 중요도 판정시 유용하게 사용될 수 있는 지표이다. 또한 위암의 생존율이 임상적 병 기에 따라 큰 차이를 나타내며 연구대상이 노인임을 감안 할 때, 본 연구대상자의 임상양상에 대한 자료가 수집되어 각 병기에 따른 생존양상에 대한 체계적인 연구가 이루어 져야 할 것이다.

\section{결 론}

한국노인약물역학코호트(KEPEC) 구성원에서 남자 표준 화 위암 발생률은 1995년 우리나라 전체 인구에 적용하여 산출하였을 때 10만인-년당 351.4명이었으며, 여자에서는 122.6명이었다. 위암사망률은 우리나라 인구구조에 표준화 하였을 때, 10만인-년당 남자에서 268.5명, 여자에서 93.7명 으로 나타났다. 그러므로, 발생률과 사망률 모두 남자가 여 자보다 약 3 배 더 높은 것으로 나타났다. 위암 5년 생존율은 남자에서 $34.8 \%$, 여자에서 $34.7 \%$ 로 전체 연령에 비하여 예 후가 좋지 않았다.

\section{감사의 글}

본 연구에 적극 협조해 주신 국민건강보험공단(구 의료 보험관리공단) 관계자 및 부산지역 병원 관계자 분과 중앙 암등록자료, 부산지역암등록자료 이용에 도움을 주신 국립 암센터의 신해림 부장님과 제주의대 배종면 교수님, 병원 방문조사에 참여하였던 서울대학교 의과대학 학생들께 감 사드립니다. 


\section{REFERENCES}

1. Korea Gastric Cancer Association. Nationwide gastric cancer report in Korea. J Korean Gastric Cancer Assoc 2002;2: 105-114.

2. Korean Cancer Registry. Annual report of Korean Central Cancer Registry Program 2002. Available from: URL: http:// www.ncc.re.kr/index.jsp.

3. Matley PJ, Dent DM, Madden MV, Price S. Gastric carcinoma in young adults. Ann Surg 1988;208:593-596.

4. Tso PL, Bringaze III WL, Dauterive AH, Correa P, Chon I. Gastric carcinoma in the young. Cancer 1987;59:1362-1365.

5. Lee CW, Lee MY, Lim HS, Shon SS, Jeon JK. Cancer incidence in Daegu in 1997-98: The first results of the Daegu Cancer Registry. J Korean Cancer Assoc 2001;33:136-148.

6. Bae JM, Won YJ, Jung KW, Suh KA, Ahn DH, Park JG. Annual report of the Central Cancer Registry in Korea 1999: Based on registered data from 128 hospitals. Cancer Res Treat 2001;33:367-372.

7. Parkin DM, Ferlay J, Whelan SL, Teppo L, Thomas DB. Cancer Incidence in Five Contents Vol. VIII Lyon; IARC Scientific Publications No. 155, 2003.

8. David S, Joseph FF. Cancer epidemiology and prevention, 2nd ed. New York, 1996.

9. Brenner H, Stegmaier C, Ziegler H. Estimating completeness of cancer registration: an empirical evaluation of the two source capture-recapture approach in Germany. J Epidemiol Community Health 1995;49:426-430.

10. Park BJ, Cho YK, Kim SA. Construction of the Korea Elderly Pharmacoepidemiologic Cohort; drug utilization review of Cephalosporins in geriatric inpatients. Pharmacoepi Drug Saf 2001;10:487-492.

11. Rothman KJ, Greenland S. Modern epidemiology, 2nd ed. Lippincott, Philadelphia, 1998.

12. Isabel dos Santos Silva. Cancer epidemiology principles and methods, France: International Agency for Research on Cancer Lyon;1999. p.105.

13. Park BJ, Lee MS, Ahn YO, Choi YM, Joo YS, Yoo KY. Nationwide incidence estimation of uterine cervix cancer among Korean women. Korean J Prevent Med 1996;29:843851.

14. Pickle LW, Feuer EJ, Edwards BK, National Cancer Institute. Prediction of incident cancer cases in non SEER counties. Proceedings of the Biometrics Section of the 2000 Annual Meeting of the American Statistical Association 2001. p. 45-52.

15. Bae JM, Lee CW, Lee DH, Ahn YO. Methods for the estimation of nationwide cancer incidence from population- based cancer registries. Korean J Epidemiol 2002;24:1-6.

16. Yoo KY, Park SK, Sung JH, Noh DY, Choe KJ. Incidence of female breast cancer in a defined area in Korea. Korean J Prevent Med 1998;31:592-603.

17. Shin MH, Ahn YO. Evaluation of the completeness and validity of the registration in the Implementation Study of Seoul Cancer Registry(ISSCR). Korean J Prevent Med 1994; 27:735-745.

18. Choi NK, Youn KE, Heo DS. Kim Y, Lee SM, Park BJ. Lung cancer incidence, mortality and survival rate in Korean Elderly Parmacoepidemiologic Cohort(KEPEC) in 1994-1998. Korean J Epidemiol 2002;24:121-130.

19. Lee SA, Kang DH, Hong SW, Shim KN, Choe JW, Choi H. Diatary habit and Helicobacter prlori infection in early gastric cancer patient. Cancer Res Treat 2002;34:104-110.

20. Haesun H, Johanna DD, Robert M, Russell MD. Diet, Helicobacter prlori infection, food preservation and gastric cancer risk: are there new roles for preventive factors? Nutrition Review 1994;52:75-82.

21. Korean National Statistical Office. 2001 Annual Reports on the cause of Death Statistics. 2002.

22. SY Oh, AS Shin, SS Hwang, KY Yoo. The association between Helicobacter prlori infection and gastric adenocarcinoma: a review of the literature. Korean J Epidemiol 2002;24: 93-106.

23. OM Jensen, DM Parkin, R Maclennan, CS Muir, RG Skeet. Cancer registration principles and methods. Lyon; IARC Scientific Publications No. 95, 1991.

24. Korean National Statistical Office. 1994 Annual Reports on the cause of Death Statistics. 1995.

25. Korean National Cancer Institute, Cancer Registry Center. 2002. Available from: URL: http://www.ncc.re.kr/CICenter/ cancerStat/survival02.doc. 